Journal of Applied Pharmaceutical Science Vol. 3 (06), pp. 152-155, June, 2013

Available online at http://www.japsonline.com

DOI: $10.7324 / \mathrm{JAPS} .2013 .3625$

ISSN 2231-3354 (cc) BY-NC-SA

\title{
Antifungal Activity of extracts from two Ouratea species on Candida albicans
}

\author{
Marcelo Francisco de Araújo*a,c, Francisco Eduardo Aragão Catunda Júnior ${ }^{\mathrm{a}, \mathrm{d}}$, M. Gabriela Alvarez ${ }^{\mathrm{b}}$, Edgardo N. \\ Durantini $^{\mathrm{b}}$, Mário Geraldo de Carvalho ${ }^{\mathrm{a}}$ \\ ${ }^{a}$ Departamento de Química, Instituto de Ciências Exatas, Universidade Federal Rural do Rio de Janeiro, Seropédica-RJ, Brazil \\ ${ }^{b}$ Departamento de Química, Universidad Nacional de Río Cuarto, Agencia Postal Nro 3, X5804BYA Río Cuarto, Argentina \\ 'Instituto Federal Fluminense-IFF campus Guarus, Campos dos Goytacazes, Rio de Janeiro, Brazil. \\ ${ }^{\mathrm{d}}$ Faculdades INTA, Sobral, Ceará, Brazil.
}

\begin{tabular}{|c|c|}
\hline ARTICLE INFO & ABSTRACT \\
\hline $\begin{array}{l}\text { Article history: } \\
\text { Received on: } 06 / 05 / 2013 \\
\text { Revised on: } 22 / 05 / 2013 \\
\text { Accepted on: } 06 / 06 / 2013 \\
\text { Available online: } 27 / 06 / 2013\end{array}$ & $\begin{array}{l}\text { Plants are invaluable sources of pharmaceutical products and Brazil, in particular, has yielded an incredible array } \\
\text { of plant and animal products that have drawn the attention of ethnopharmacologists from around the world. } \\
\text { Ouratea is a genus of tropical plants within the Ochnaceae. Ouratea is widespread throughtout the tropics, with } \\
\text { species in Costa Rica, Brazil, Jamaica, and Kenya. The search for compounds with antimicrobial activity is } \\
\text { urgent and indispensable for the treatment of infectious diseases caused by microorganisms resistant to traditional } \\
\text { antimicrobial drugs. A screening was conducted with organic extracts from two species, from roots and leaves of }\end{array}$ \\
\hline $\begin{array}{l}\text { Key words: } \\
\text { antifungal activity; Ouratea; } \\
\text { Ochnaceae; Candida } \\
\text { albicans. }\end{array}$ & $\begin{array}{l}\text { Ouratea hexasperma var. planchonii Engl. and leaves and branches of Ouratea parviflora Engl., to identify plant } \\
\text { extracts with antifungal properties against Candida albicans. Initially, minimal inhibitory concentrations (MICs) } \\
\text { were determined in C. albicans cellular suspension in Sabouraud medium, in a range of } 0.060-3.0 \mathrm{mg} / \mathrm{ml} \text {. } \\
\text { Fractions OHRMWE (Ethyl acetate fraction) and OHLMWB (Buthanol fraction) obtained by solvents partition } \\
\text { of methanol:water extract from Ouratea hexasperma with ethyl acetate from the roots and } n \text {-butanol from the } \\
\text { leaves, respectively, showed a higher antifungal activity. The antifungal activity of these extracts was also } \\
\text { compared in growth delay of } C \text {. albicans cultures. }\end{array}$ \\
\hline
\end{tabular}

\section{INTRODUCTION}

The genus Ouratea (Ochnaceae) comprises ca 300 tropical species occurring mainly in South America (Heywood, 1978). Some species of this genus have been shown to possess antiviral (Ouratea lucens, from Panama) (Roming et al., 1992), antimicrobial (O. parviflora, from Brazil) (Paulo et al., 1986), as well as pain relief ( $O$. reticulata, from Guinea) activities (Vasileva, 1969). Previous phytochemical and pharmacological investigations on Ouratea species have shown the presence of terpenoids, isoflavonoids, flavonoid glycosides, and more frequently biflavones which are considered as chemical markers for the genus (Suzart et al., 2007). DNA topoisomerase inhibition, cytotoxic and antitumoral activities of biflavonoids (Carvalho et al., 2002; Grynberg et al., 2002; Daniel et al., 2007) have been described as well as other pharmacological activities of extracts

\footnotetext{
* Corresponding Author

Marcelo Francisco de Araújo,

Avenida Souza Mota, 350 - Parque Fundão, 28060-010-

Campos dos Goytacazes-RJ + 55 22-2737-2400;
}

from Ouratea species (Cortes et al., 2002; Gonçalves et al., 2001; Sampaio and Oliveira, 1975). Extracts of some plants are toxic to fungi and may be useful for controlling fungal growth and mycotoxin production (Steinhart et al., 1996). Substances isolated from plants such as flavonoids, isoflavonoids and biflavonoids, besides other activities, have shown activity against some aspects of fungal metabolism (Weidenborner et al., 1990; Weidenborner et al., 1989; Mallozzi et al., 1996; Norton, 1999). The utilization of extracts and natural compounds have been substituted of conventional treatment against microorganisms in order to prevent contamination has been considered because some flavonoids are biologically active (Gonçalves et al., 2001). Oral candidiasis is a significant infection in patients being treated with chemotherapy and radiotherapy for cancer, and in patients who are immunocompromised because of HIV infection and AIDS. $C$. albicans is the most common fungal pathogen and has developed an extensive array of recognized virulent mechanisms that allows successful colonization and infection of the host under suitable predisposing conditions (White et al., 2002). 
Antimicrobial resistance is a growing problem that complicates the treatment of important nosocomial and community-acquired infections. In the last years, resistance of $C$. albicans is increasing against traditional antifungal, such as fluconazole (Goldman et al., 2004; Briona et al., 2007; Ribeiro and Rodrigues, 2007). In the present study, we have evaluated the antifungal activity of different extracts from $O$. hexasperma and $O$. parviflora on C. albicans.

\section{MATERIAL AND METHODS}

\section{General}

Absorption spectra were recorded on a Shimadzu UV2401PC spectrometer. All the chemicals from Aldrich (Milwaukee, WI, USA) were used without further purification. Solvents (GR grade) from Merck were distilled. Ultrapure water was obtained from Labconco (Kansas, MO, USA) equipment model 90901-01.

\section{Plan Materials}

The leaves and roots of $O$. hexasperma var. planchonii Engl. were collected in the sandbank area, Jacunã beach, Conde city, Paraíba state, Brazil. It was identified by Prof. Dra. Maria de Fátima Agra. Voucher specimen (№ 6747) is deposited at the Prof. Lauro Pires Xavier (JPB) Herbarium, UFPB, João Pessoa-PB, Brazil.

The leaves and branchs of $O$. parviflora Engl. were collected in the Ouro Preto city, Minas Gerais state, Brazil by Prof $^{a}$ Dr $^{a}$ Alceni Augusta Werle, Dpt ${ }^{\circ}$ de Química, ICEB, UFOP. It was identified by Prof $^{\circ}$ Dr. Elsie F. Guimarães. Voucher specimen ( $\mathrm{N}^{\mathrm{o}} \mathrm{RB}$ 44,334) is deposited at the JBRJ Herbarium, Jardim Botânico, Rio de Janeiro-RJ, Brazil.

\section{Extracts}

The dried and powder leaves $(2.127 \mathrm{~kg})$ and roots $(3.133$ $\mathrm{kg}$ ) of $O$. hexasperma were extracted with methanol and methanol:water (80:20) at room temperature and the solvents was removed under vacuum to afford $377.8 \mathrm{~g}$ of leaves methanol extract and $209.8 \mathrm{~g}$ of roots methanol extracts, besides afforded $170.0 \mathrm{~g}$ of leaves methanol:water extract and $160.5 \mathrm{~g}$ of roots methanol:water extract.

The leaves methanol extract was partitioned into dichlorometane, ethyl acetate and methanol:water (90:10) to afford the dichlorometane fraction (OHLMD), the ethyl acetate fraction (OHLME) and the methanol fraction (OHLMM). The leaves methanol:water (80:20) extract was partitioned into dichlorometane, ethyl acetate, n-buthanol and methanol:water (90:10) to afford the dichlorometane fraction (OHLMWD), the ethyl acetate fraction (OHLMWE), the buthanol fraction (OHLMWB) and the methanol fraction (OHLMWM). The roots methanol extract was partitioned into ethyl acetate e methanol:water (90:10) to afford the ethyl acetate fraction (OHRME) and methanol fraction (OHRMM). The roots methanol:water (80:20) was partitioned into ethyl acetate, n- buthanol and methanol:water (90:10) to afford the ethyl acetate fraction (OHRMWE), the buthanol fraction (OHRMWB) and the methanol fraction (OHRMWM). The dried and powder leaves $(821.0 \mathrm{~g})$ and branches (293.8 g) of O. parviflora were extracted with methanol at room temperature and the solvent was removed under vacuum to afford $326.0 \mathrm{~g}$ of leaves methanol extract (OPLM) and $37.5 \mathrm{~g}$ of branches methanol extract (OPBM).

\section{Microorganism and growth conditions}

C. albicans strain PC31, recovered from human skin lesion, was previously characterized and identified according to conventional procedures (Cormick et al., 2008; Harrigan and Mccance, 1986). Primary classification of colonies from plates was based on colony characteristic (pigmentation and shape), mode of vegetative reproduction, formation of pseudohyphae and ascopore production.

Identification of the yeast isolates to species level was done using the API 20C AUX (BioMérieux, Marcy 1'Etoile, France) system of carbohydrate assimilation profiles. Strain of $C$. albicans was grown aerobically overnight in Sabouraud (Britania, Buenos Aires, Argentina) broth $(4 \mathrm{ml})$ at $37^{\circ} \mathrm{C}$ to stationary phase. Viable $C$. albicans cells were monitored and the number of colony forming units (CFU) was determined on Sabouraud agar plates and $\sim 48 \mathrm{~h}$ incubation at $37^{\circ} \mathrm{C}$. This procedure produces $\sim 10^{7} \mathrm{CFU} / \mathrm{mL}$ after an overnight incubation.

\section{Antimicrobial activity of extracts}

After overnight incubation, the cells were appropriately diluted to obtain $\sim 10^{4} \mathrm{CFU} / \mathrm{ml}$ in Sabouraud broth. In all the experiments, $2 \mathrm{ml}$ of the cell suspensions in Pirex brand culture tubes $(13 \times 100 \mathrm{~mm})$ were used and the extracts were added from a stock solution $\sim 10 \mathrm{mg} / \mathrm{mL}$ in $N, N$-dimethylformamide: water (1:1). The minimal inhibitory concentration (MIC) values were considered to be the lowest concentration of sample able to totally inhibit microbial growth (range 0.064-3.0 mg/ml). The MICs were determined after $48 \mathrm{~h}$ incubation at $37{ }^{\circ} \mathrm{C}$. Prior to the assays, it was verified that the loading solvent, $\mathrm{N}, \mathrm{N}$ dimethylformamide:water (1:1), was completely inactive against the test organisms under the assay conditions. Also, control experiments were carried out under the same conditions in the absence of extracts. Each experiment was repeated separately three times.

\section{Growth delay of C. albicans}

Cultures of $C$. albicans cells were grown overnight as described above. A portion $(1 \mathrm{ml})$ of this culture was transfer to 20 $\mathrm{ml}$ of fresh Sabouraud broth medium. The suspension was homogenized and aliquots of $2 \mathrm{ml}$ were incubated with different concentration of the extracts at $37{ }^{\circ} \mathrm{C}$. The culture grown was measured by turbidity at $660 \mathrm{~nm}$ using a Tuner SP-830 spectrophotometer. In all cases, control experiments were carried out in the absence of the extracts. Each experiment was repeated separately three times. 


\section{STATISTICAL ANALYSIS}

All data were presented as the mean \pm standard deviation of each group. Variation between groups was evaluated using the Students $t$-test, with a confidence level of $95 \% \quad(p<0.05)$ considered statistically significant.

\section{RESULT AND DISCUSSION}

\section{Antimicrobial activity of extracts on C. albicans}

The biological activity of extracts form various plant parts of two species $O$. hexasperma and $O$. parviflora were investigated on $C$. albicans cellular suspension in Sabouraud medium. The extracts were evaluated in a range of 0.060-3.0 $\mathrm{mg} / \mathrm{ml}$. The results of MICs are summarized in figure 1 . As can be observed, OHRMWE (Ethyl acetate fraction) and OHLMWB (Buthanol fraction) showed a higher antifungal activity. Only this extracts from roots and leaves of $O$. hexasperma exhibited activity against the yeast $C$. albicans. Although the root wood extract with ethyl acetate from this species was more active than that from leaves with $n$-buthanol. In contrast, the other extracts were less effective to inactivate $C$. albicans.

Table. 1: Antifungal activity of Ouratea hexasperma (OH) and Ouratea parviflora (OP) extracts on Candida albicans.

\begin{tabular}{|c|c|c|c|}
\hline Extracts* & Species & $\begin{array}{c}\text { Plant part } \\
\text { assayed }\end{array}$ & MIC (mg/ml) \\
\hline OHLME & \multirow{12}{*}{ Ouratea hexasperma } & leaves & 2.500 \\
\hline OHLMD & & leaves & 1.250 \\
\hline OHRMWB & & roots & 1.250 \\
\hline OHLMM & & leaves & 1.250 \\
\hline OHLMWE & & leaves & 1.250 \\
\hline OHLMWM & & leaves & 1.250 \\
\hline OHRMWE & & roots & 0.500 \\
\hline OHLMWD & & leaves & 1.250 \\
\hline OHLMWB & & leaves & 0.625 \\
\hline OHRMWM & & roots & 2.500 \\
\hline OHRMM & & roots & 2.500 \\
\hline OHRME & & roots & 2.500 \\
\hline OPBM & \multirow{2}{*}{ Ouratea parviflora } & branches & 2.500 \\
\hline OPLM & & leaves & 2.500 \\
\hline \multicolumn{4}{|c|}{$\begin{array}{l}\text { *OHLME (Ethyl acetate fraction), OHLMD (Dichlorometane fraction), } \\
\text { OHRMWB (Buthanol fraction), OHLMM (Methanol fraction), OHLMWE } \\
\text { (Ethyl acetate fraction), OHLMWM (Methanol fraction), OHRMWE (Ethyl } \\
\text { acetate fraction), OHLMWD (Dichlorometane fraction), OHLMWB (Buthanol } \\
\text { fraction), OHRMWM (Methanol fraction), OHRMM (Methanol fraction), } \\
\text { OHRME (Ethyl acetate fraction), OPBM (Methanol extract), OPLM (Methanol } \\
\text { extract). }\end{array}$} \\
\hline
\end{tabular}

Taking into account these results, growth delay of $C$. albicans cultures produced by extracts OHRMWE and OHLMWB was carried out in Sabouraud medium. Thus, different amounts of extracts were added to fresh cultures of $C$. albicans reaching the $\log$ phase and the flasks were incubated at $37{ }^{\circ} \mathrm{C}$. Three concentrations of extracts, under and over MIC value, were analyzed under these conditions. As can be observed in Figure 1, growth was suppressed when $C$. albicans cultures were treated with both extracts using concentration identical or up than MIC. After $30 \mathrm{~min}$ of incubation in the presence of 0.4 or $0.5 \mathrm{mg} / \mathrm{ml}$ of OHRMWE, the cells no longer appeared to be growing as measured by turbidity at $660 \mathrm{~nm}$. Under these conditions, the effect of OHRMWE is faster than that of OHLMWB. On the other hand, $C$. albicans cells incubated with a lower concentration of extracts (under MIC value) showed only a small growth delay compared with controls. Therefore, the data illustrate that the observed growth delay is due to the antimicrobial effect of these two extracts on the cells.

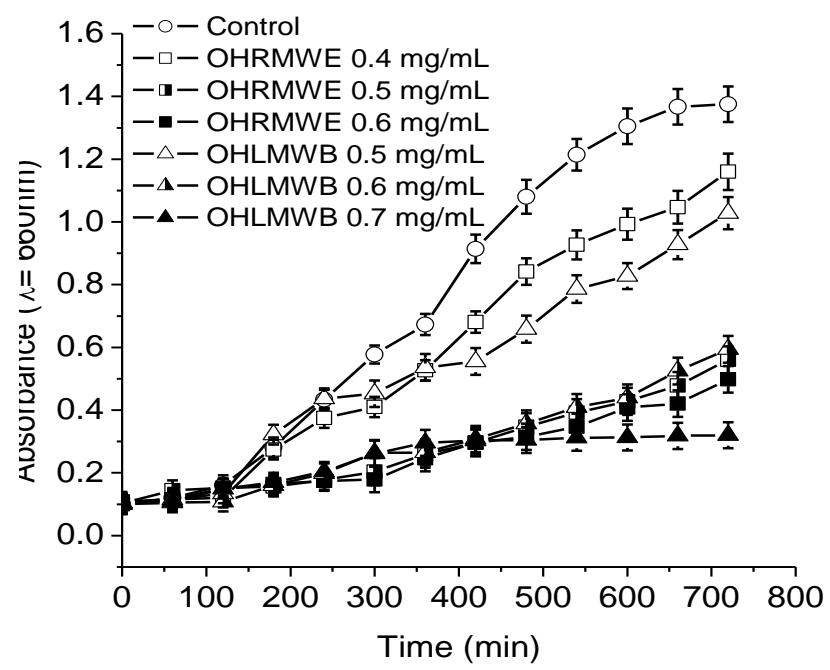

Fig. 1: Growth delay curves of $C$. albicans cells incubated with different concentrations of fractions OHRMWE (squares) and OHLMWB (triangles) in Sabouraud broth at $37{ }^{\circ} \mathrm{C}$. Control cultures: cells without extracts (O). Values represent mean \pm standard deviation of three separate experiments.

\section{CONCLUSION}

This preliminary screening is an interesting evaluation of the potential antifungal of $O$. hexasperma var. planchonii Engl. and $O$. parviflora Engl. against the strains of Candida albicans. Further studies need to be carried out to define active principle(s) of fractions and to study the relation between chemical structure and antifungal activity.

\section{REFERENCES}

Heywood VH. 1978. In Flowering Plants of the World. Oxford University Press. London.

Roming TL, Weber ND, Murray B K, North JA, Wood JC, Hughs AG, Cates RG. Antiviral Activity of Panamanian Plant-Extracts. Phytother Res, 1992; 6: 38-43

Paulo MQ, Lima EO, Maia RF, Filho XL. Antimicrobial activity for the oil of fruit of Ouratea Parviflora Baill. Ochnaceae. Chin Chiao I Sheng Tsa Chin,1986; 83: 19-21.

Vasileva B. 1969. Plantes Medicinales de Guine; Conakry, Rep. De Guine, Moscow, Univ. Moscow-USSK.

Suzart LR, Daniel JF de S, Carvalho MG de, Kaplan MAC. Biodiversidade Flavonoídica e Aspectos Farmacológicos em Espécies dos Gêneros Ouratea E Luxemburgia (Ochnaceae). Quimica Nova, 2007; 30: 984-987.

Carvalho MG de, Velandia JR, de Oliveira JCC, Echevarria A, Braz-Filho R, Grynberg NF. 2002. In Phytochemical and Pharmacologiy II of the Series "Recent Progress in Medicinal Plants", Majumdar DK, Govil JN, Singh V K eds., SCI Tech Publishing LLC: Texas, 77-92.

Grynberg NF, Carvalho MG de, Velandia JR, Oliveira MC, Moreira IC, Braz-Filho R, Echevarria A. DNA topoisomerase inhibitors: biflavonoids from Ouratea species Braz J Med Biol Res, 2002; 35: 819822. 
Daniel JF de S, Alves CCF, Grivicich I, Rocha AB da, Carvalho MG de. Antitumor activity of biflavonoids from Ouratea and Luxemburgia on human cancer cell lines. Indian J Pharmacol, 2007; 39: 184-186.

Cortes SF, Veladares JY, Oliveira AB de, Lemos SV, Barbosa MPT, Braga FC. Mechanism of endothelium-dependent vasodilation induced by a proanthocyanidin-rich fraction from Ouratea semiserrata. Planta Medica, 2002; 68: 412-415.

Gonçalves E, Felicio JD, Pinto MM. Biflavonoids inhibit the production of $1453-1456$

aflatoxin by Aspergillus flavus. Braz J Med Biol Res, 2001; 34:

Sampaio MP, Oliveira MM de. Triagem de substâncias de extratos de origem vegetal no carcinossarcoma da Walker 256. An. Acad. Bras. Cienc. 1975; 47: 149-153.

Steinhart CE, Doyle ME, Cochrane BA. 1996. Food Safety. Marcel Dekker, Inc., New York, NY, USA, 376-394.

Weidenborner $\mathrm{M}$, Hindorf $\mathrm{H}$, Jha $\mathrm{CH}$, Tsotsonos $\mathrm{P}$. Antifungical activity of flavonoids against storage fungi of the genus Aspergillus. Phytochemistry, 1990; 29:1103-1105.

Weidenborner M, Hindorf $\mathrm{H}$, Jha $\mathrm{CH}$, Tsotsonos P, Egge $\mathrm{H}$. Antifungical activity of isoflavonoids against storage fungi of the genus Aspergillus. Phytochemistry, 1989; 28: 3317-3319.

Mallozzi MAB, Corrêa B, Haraguchi M, Brignani FN. Effect of flavonoids on Aspergillus flavus growth and aflatoxin production. Revista de Microbiologia, 1996; 27:161-167.

Norton RA. Inhibition of aflatoxin B1 biosynthesis in Aspergillus flavus by anthocyanidins and related flavonoids. Journal of Agricultural and Food Chemistry, 1999; 47: 1230-1235.
White TC, Holleman S, Dy F, Mirels LF, Stevens DA. Resistance mechanisms in clinical isolates of Candida albicans. Antimicrob Agents Chemother, 2002; 46: 1704-1713.

Goldman GH, Ferreira MES, Marques ER, Savoldi M, Perlin D, Park S, Martinez PCG, Goldman MHS, Colombo AL. Evaluation of fluconazole resistance mechanisms in Candida albicans clinical isolates from HIV-infected patients in Brazil. Diagn Micr Infec Dis, 2004; 50: 2532.

Briona LP, Ukoa SE, Goldmanb DL. Risk of resistance associated with fluconazole prophylaxis: Systematic review. J Infection, 2007; 54: 521-529.

Ribeiro MA, Rodrigues CP. Up-regulation of ERG11 gene among fluconazole-resistant Candida albicans generated in vitro: is there any clinical implication? Diagn Micr Infec Dis, 2007; 57: 71-75.

Cormick MP, Rovera M, Durantini EN. Synthesis, spectroscopic properties and photodynamic activity of a novel $\mathrm{Zn}$ (II) phthalocyanine substituted by fluconazole groups. J Photochem Photobiol A: Chem, 2008; 194: 220-229.

Harrigan WF, McCance ME. 1986. Laboratory methods in food and dairy microbiology, Academic Press, London.

\section{How to cite this article:}

Marcelo Francisco de Araújo, Francisco Eduardo Aragão Catunda Júnior, M. Gabriela Alvarez, Edgardo N. Durantini, Mário Geraldo de Carvalho., Antifungal Activity of extracts from two Ouratea species on Candida albicans. J App Pharm Sci. 2013; 3 (06): 152155. 